\title{
Analisis Bibliometrika Tingkat Kolaborasi, Produktivitas Penulis, Serta Profil Artikel Jurnal Kajian Informasi \& Perpustakaan Tahun 2014-2018
}

\author{
Rohanda dan Yunus Winoto \\ Universitas Padjadjaran \\ Jl. Raya Jatinangor Sumedang Km.21, Bandung
}

\begin{abstract}
The purpose of the study was to identify articles published in the Science \& Library Progress Journal in 2014 - 2018. The subject of this study is 76 articles published online by the information and library study journal for the period 2014-2018. The method of data collection is done by checking and recording all information related to the number of articles, number of citations, number of authors, authorship and collaboration, the level of author productivity, the level of collaboration and the distribution of agencies and professional writers. The analytical method used is a qualitative descriptive method and calculates the level of collaboration using the Subramayan formula. The results of the study showed that of the total 76 articles, the highest number of articles written by 3 authors is 45 articles (59.21\%) with a collaboration degree of 0.89 . The author who ranked first in the author's productivity was Pawit M. Yusup who has written 12 articles in JKIP in 2014-2018. The institution that most often participates in article writing is the Department of Library Science at Padjadjaran University, which is 139 times (76.36\%). The profession of the writers who participated most in writing articles was from the lecturers, namely 119 times (65.38\%).
\end{abstract}

Keywords: bibliometrics; collaboration level; author productivity;profile of article 


\begin{abstract}
Abstrak
Tujuan kajian adalah untuk mengidentifikasi artikel yang dimuat dalam Jurnal Kajian Ilmu \& Perpustakaan pada tahun 2014 - 2018. Data kajian diambil dari 76 artikel yang dipublikasikan secara online oleh jurnal kajian informasi dan perpustakaan periode 2014 - 2018. Metode pengumpulan data dilakukan dengan memeriksa dan mencatat seluruh informasi terkait jumlah artikel, jumlah sitiran, jumlah penulis, kepengarangan secara inidivdu dan kolaborasi, tingkat produktivitas penulis, tingkat kolaborasi serta sebaran instansi dan profesi penulis. Metode analisis yang digunakan adalah metode deskriptif kualitatifdan menghitung tingkat kolaborasi menggunakan rumus Subramayan.Hasil kajian menunjukan bahwa dari total keseluruhan 76 artikel, jumlah artikel terbanyak ditulis oleh 3 orang pengarang yaitu sebanyak 45 judul artikel (59,21\%) dengan derajat kolaborasi sebesar 0,89. Penulis yang menduduki peringkat pertama dalam produktivitas penulis adalah Pawit M. Yusup yang telah menulis 12 artikel dalam JKIP tahun 2014-2018. Instansi yang paling berpartisipasi dalam penulisan artikel adalah Prodi Ilmu Perpustakaan Universitas Padjadjaran yaitu sebanyak 139 kali (76,36\%). Adapun profesi penulis yang paling banyak berpartisipasi dalam penulisan artikel adalah dari kalangan dosen yaitu sebanyak 119 kali (65,38\%).
\end{abstract}

Kata kunci: bibliometrik; tingkat kolaborasi; produktifitas penulis; profil artikel

\title{
Pendahuluan
}

Jurnal ilmiah adalah sebuah publikasi yang diterbitkan secara berkala oleh suatu organisasi profesi atau institusi akademik yang memuat artikelartikel yang merupakan produk pemikiran ilmiah secara empiris (artikel hasil penelitian) maupun secara logis (artikel hasil pemikiran) dalam bidangi lmu tertentu (Suryoputro, Riadi dan Sya’ban 2012).

Sedangkan pengertian artikel ilmiah (research articles) menurut Adnan adalah tulisan yang berisi laporan sistematis mengenai hasil kajian atau hasil penelitian yang disajikan bagi masyarakat ilmiah tertentu, yang merupakan audiens khusus dengan tujuan menyampaikan hasil kajian dan kontribusi penulis artikel kepada mereka untuk dipikirkan, dikaji kembali, dan didiskusikan, baik secara lisan maupun tertulis. Yang dimaksud dengan audien khusus antara lain seperti mahasiswa, dosen, peneliti dan ilmuwan ((Adnan, Zifirdaus dan Zifirdaus 2005) dalam Buku (Suryoputro, Riadi dan Sya'ban 2012)). 
Kebutuhan akan ilmu pengetahuan membuat semakin banyak penelitian yang dilakukan dan dilaporkan kedalam artikel ilmiah untuk menjadi bahan pengajaran. Semakin banyaknya karya tulis ilmiah hasil dari penelitian, menjadi faktor berkembangnya ilmu lain dan munculnya ilmu baru. Salah satunya adalah Bibliometrik. Bibliometrik memang merupakan ilmu yang sudah ada pada 1980an dibidang Ilmu Perpustakaan, akan tetapi ilmu ini tetap dipakai dan dipelajari selama artikel ilmiah masih terus bermunculan.

Bibliometrik adalah penerapan metode matematika dan statistika untuk buku dan media komunikasi lainnya. Bibliometrika mulai digunakan untuk mengevaluasi produktifitas penulis dan dampak keilmuan (scientific impact) terhadap riset pada tahun 1980an (Gingras 2014) (Rahayu dan Saleh 2017). Ilmu ini dikenalkan oleh Pritchard pada tahun 1980-an, yang dapat dimaknai sebagai kajian yang mengacu pada analisis secara matematis dan statistik terhadap pola-pola yang terjadi dalam publikasi dan penggunaan dokumen (Widuri 2018)

Dapat disimpulkan bahwa Bibliometrik merupakan ilmu yang mengkaji tentang kepenulisan dengan menggunakan analisis matematis dan statistik. Dengan adanya ilmu ini kita akan mengetahui hal-hal tentang kepenulisan, salah satunya ada produktivitas pengarang. Seorang pengarang dapat dinilai produktif atau tidaknya dengan melihat jumlah karya yang ia tulis dalam kurun waktu tertentu, baik itu hasil karya sendiri tanpa membutuhkan penulis lain, ataupun hasil dari kolaborasi antar penulis.

Dari pemaparan tersebut, menimbulkan sebuah pertanyaan yang menumbuhkan ketertarikan untuk mengetahui seberapa produktif penulis dalam membuat karya ilmiah dalam sebuah jurnal dalam kurun waktu tertentu.

Jurnal yang diteliti yaitu Jurnal Kajian Informasi \& Perpustakaan (JKIP) adalah jurnal yang diambil dari penelitian dan laporan penelitian tentang Ilmu Informasi dan Perpustakaan. Jurnal Kajian Informasi \& Perpustakaan diterbitkan dua kali setiap tahun (Juni dan Desember) oleh para 
editor jurnal dari Program Studi Perpustakaan Fakultas Ilmu Komunikasi, Universitas Padjadjaran yang bekerja sama dengan Ikatan Sarjana Ilmu Perpustakaan dan Informasi Indonesia (ISIPII) dan Asosiasi Jawa Barat Indonesia. Pustakawan (IPI) (Jurnal Kajian Informasi \& Perpustakaan Website 2018).

Penelitian ini menggunakan obyek artikel dari Jurnal Kajian Informasi \& Perpustakaan dari tahun 2014 s.d. 2018. Penelitian ini bertujuan untuk mengetahui tingkat kolaborasi, produktivitas penulis, dan profil artikel yang dimuat pada Jurnal Kajian Informasi \& Perpustakaan. Hal inimeliputi: 1) Deskripsi artikel; 2) Referensi yang digunakan; 3) Jenis bahasa artikel; 4) Jumlah penulis; 5) Tingkat kolaborasi penulis; dan 6) Produktivitas penulis.

\section{Tinjauan Pustaka}

\section{1) Jurnal Ilmiah}

Artikel atau jurnal merupakan literature primer yang sangat penting. Jurnal memiliki frekuensi terbit yang relatif cepat dan teratur, sehingga artikelartikel yang dimuat lebih mutakhir. Jurnal ilmiah merupakan terbitan berkala yang diterbitkan oleh instansi pemerintah, akademik maupun organisasi profesi. Artikel-artikel di jurnal ilmiah merupakan produk pemikiran ilmiah secara empiris (artikel hasil penelitian) dan logis (artikel hasil pemikiran) dalam suatu bidang tertentu (Suryoputro, Riadi, \& Sya'ban, 2012).SulistyoBasuki menuturkan bahwa artikel ilmiah artinya artikel yang memperluas pengetahuan berdasarkan hasil penelitian (Sulistyo-Basuki, 2004).

\section{2) Tingkat Kolaborasi}

Kolaborasi dalam bahasa inggris "collaboration" memiliki makna kerjasama. Sejarah kolaborasi muncul sejak lahirnya sebuah ilmu pengetahuan. Dalam publikasi penelitian, kolaborasi dapat meningkatkan popularitas suatu kegiatan dan dapat mempengaruhi proses dan hasil yang dicapai. Dalam konteks penelitian, kolaborasi penulisan diperlukan, mengingat tidak selamanya penelitian dilakukan secara individu. Karena hal tersebut, maka dibutuhkan kerjasama antar peneliti maupun antar 
instansi baik dalam hal gagasan atau ide, pendanaan, sarana dan peralatan. Sutarsyah (2014) menjelaskan beberapa keuntungan yang diperoleh penulis bila berkolaborasi, yakni memungkinkan adanya kesempatan berbagi pengetahuan, keahlian, dan teknik-teknik tertentu dalam sebuah ilmu. Keuntungan lainnya adalah membantu memecahkan permasalahan yang kompleks, sehingga menghasilkan KTI dengan kualitas yang lebih baik (Widuri 2018, 64).

\section{3) Produktivitas Penulis}

Menurut Lotka (1926) produktivitas penulis adalah banyaknya karya tulis yang dihasilkan oleh seseorang secara individual maupun secara kolaborasi dalam subjek tertentu dan diterbitkan pada jurnal-jurnal ilmiah baik dalam skala nasional maupun internasional dalam subjek tertentu dan dalam kurun waktu tertentu. Produktivitas penulis disebut juga produktivitas ilmiah, produktivitas ilmiah menunjukkan jumlah publikasi ilmiah baik yang terindeks maupun tidak terindeks secara nasional dan internasional (Andreas 2009).

Mengukur produktivitas penulis menurut Dewiyana \& Arianti (2009) berfungsi untuk mengetahui penulis-penulis produktif dan yang paling produktif dalam jurnal ilmiah dan kurun waktu tertentu. Hal yang sama juga disampaikan oleh Diodata (1994), yang mendefinisikan bahwa produktivitas ilmiah sebagai jumlah penelitian yang dihasilkan ilmuwan. Produktivitasi lmiah di berbagai bidang ilmu dapat diukur melalui berbagai data seperti jumlah publikasi yang dihasilkan oleh penulis dan jumlah kutipan dari publikasi penulis tersebut (Tupan, 2017).

\section{Metode Penelitian}

Data yang digunakan dalam kajian analisis bibliometrik ini adalah seluruh artikel yang dipublikasikan secara online oleh Jurnal Kajian Informasi dan Perpustakaan periode 2014-2018, mulai dari Vol. 2 (1) tahun 2014 sampai dengan Vol. 6 (1) tahun 2018, yaitu sebanyak 76 artikel dari jumlah terbitan yang diterbitkan oleh JKIP pada tahun 2014-2018, yaitu sebanyak 9 nomor 
terbitan. Data-data tersebut diperoleh dari artikel yang dibaca dan diunduh dari alamat http://jurnal.unpad.ac.id/jkip/issue/archive.

Metode pengumpulan data pada analisis bibliometrik ini dilakukan dengan cara memeriksa setiap artikel dan mencatat seluruh informasi yang berkaitan dengan profil artikel (seperti jumlah artikel dan referensi yang digunakan), mencatat nama-nama penulis beserta judul artikel yang ditulis pada setiap nomor terbit, serta mencatat instansi asal dan profesi penulis tersebut. Kemudian data yang telah diperoleh tadi dikelompokkan ke dalam beberapa kelompok dalam bentuk tabel, yaitu :

- Jumlah artikel

- Jumlah sitiran yang digunakan

- Jumlah penulis pada setiap artikel

- Kepengarangan perorangan dan kolaborasi pada setiap artikel

- Tingkat kolaborasi penulisan artikel JKIP tahun 2014-2018

- Peringkat produktivitas penulis artikel JKIP tahun 2014-2018

- Sebaran instansi dan profesi penulis

Metode analisis yang digunakan dalam kajian ini adalah metode deskriptif kualitatif dengan analisis bibliometrik. Setiap data yang telah diubah bentuknya menjadi tabel tadi kemudian akan digambarkan secara deskriptif berdasarkan deskripsi artikel, jumlah referensi yang digunakan, bahasa artikel, jumlah penulis, tingkat kolaborasi penulis, produktivitas penulis, serta sebaran instansi dan profesi penulis. Adapun untuk menentukan tingkat kolaborasi penulis, dilakukan perhitungan menggunakan rumus Subramayan (1983), yaitu:

Di mana:

$$
\mathrm{C}=\frac{N_{m}}{N_{m+N_{s}}}
$$

$\mathrm{C}=$ tingkat kolaborasi

$\mathrm{N}_{\mathrm{m}}$ = total hasil penelitian yang dilakukan secara kolaborasi

$\mathrm{N}_{\mathrm{s}}$ = total hasil penelitian yang dilakukan secara individu 
Keterangan, Jika :

- Nilai $\mathrm{C}=0$, maka dapat dikatakan bahwa hasil penelitian seluruhnya dilakukan secara individu

- Nilai C lebih besar dari nol dan kurang dari 0,5 $(0<\mathrm{C}<0,5)$, maka dapat dikatakan bahwa hasil penelitian yang dilakukan secara individu lebih besar daripada yang dilakukan secara kolaborasi

- Nilai $\mathrm{C}=0,5$ maka penelitian yang dilakukan secara individual sama banyaknya dengan yang dilakukan secara kolaborasi

- Nilai C lebih besar dari 0,5 dan kurang dari $1(0,5<\mathrm{C}<1)$ dapat dikatakan bahwa hasil penelitian yang dilakukan secara kolaborasi lebih banyak daripada yang dilakukan secara individu.

\section{Hasil dan Pembahasan}

\section{1) Deskripsi Artikel}

Deskripsi artikel di sini meliputi jumlah nomor terbitan dan jumlah artikel yang dimuat pada Jurnal Kajian Informasi dan Perpustakaan (JKIP). Dalam periode 2014 sampai 2018, JKIP telah menerbitkan 9 nomor jurnal. Pada tahun 2014 hingga 2017, JKIP menerbitkan 2 nomor dalam satu volume, namun di tahun 2018 JKIP hanya menerbitkan 1 nomor dalam satu volume. selama tahun 2014 hingga 2018, JKIP telah memuat artikel sebanyak 76 yang dimuat dalam 9 nomor dengan rata-rata setiap nomor terbitan memuat sebanyak 7 artikel. JKIP memuat artikel terbanyak pada Vol. 3 (2), 2015 dan Vol. 4 (1), 2016 yaitu sebanyak 12 artikel, sedangkan terbitan lainnya rata-rata memuat artikel sebanyak 7 buah. Adapun mengenai distribusi artikel pada setiap volume dan tahun dapat dilihat pada table sebagai berikut :

Tabel 1. Deskripsi Jurnal yang Dikaji

\begin{tabular}{ccc}
\hline No & Volume (Nomor), Tahun & Jumlah Artikel \\
\hline 1 & Vol.2 (1), 2014 & 7 \\
\hline 2 & Vol. 2 (2), 2014 & 7 \\
\hline 3 & Vol. 3 (1),2015 & 10 \\
\hline
\end{tabular}




\begin{tabular}{ccc}
\hline No & Volume (Nomor), Tahun & Jumlah Artikel \\
\hline 4 & Vol. 3 (2), 2015 & 12 \\
\hline 5 & Vol. 4 (1), 2016 & 12 \\
\hline 6 & Vol. 4 (2), 2016 & 7 \\
\hline 7 & Vol. 5 (1), 2017 & 7 \\
\hline 8 & Vol. 5 (2), 2017 & 7 \\
\hline 9 & Vol. 6 (1), 2018 & 7 \\
\hline Total & 9 & 76 \\
\hline
\end{tabular}

Sumber : Data Penelitian

\section{2) Referensi yang Digunakan}

Selama kurun waktu 2014-2018, jumlah judul referensi yang telah disitir oleh 76 artikel yang dimuat di JKIP adalah sebanyak 1.013 judul referensi. Terbitan yang paling banyak menggunakan sumber referensi adalah pada Vol. 3 (2), 2015 yaitu sebanyak 186 judul referensi (18,36\%) dan yang paling sedikit menggunakan sumber referensi adalah pada Vol. 4 (2), 2016 yaitu sebanyak 65 judul referensi (6,42\%). Jumlah sitiran yang digunakan artikel pada tiap terbitan dapat dimuat secara rinci pada Tabel 2.

\section{Tabel 2. Jumlah Sitiran}

\begin{tabular}{cccc}
\hline No & Volume (nomor), tahun & Jumlahsitiran & Persentase (\%) \\
\hline 1 & Vol. 2 (1), 2014 & 84 & $8,29 \%$ \\
\hline 2 & Vol. 2 (2), 2014 & 97 & $9,58 \%$ \\
\hline 3 & Vol. 3 (1), 2015 & 146 & $14,41 \%$ \\
\hline 4 & Vol. 3 (2), 2015 & 186 & $18,36 \%$ \\
\hline 5 & Vol. 4 (1), 2016 & 90 & $8,88 \%$ \\
\hline 6 & Vol. 4 (2), 2016 & 65 & $6,42 \%$ \\
\hline 7 & Vol. 5 (1), 2017 & 85 & $8,40 \%$ \\
\hline 8 & Vol. 5 (2), 2017 & 122 & $12,04 \%$ \\
\hline 9 & Vol. 6 (1), 2018 & 138 & $13,62 \%$ \\
\hline Jumlah & & 1.013 & $100 \%$ \\
\hline
\end{tabular}

Sumber : Data Penelitian 


\section{3) Jenis Bahasa Artikel}

Bahasa yang digunakan dalam total 76 artikel yang dimuat pada JKIP periode 2014-2018 secara keseluruhan adalah Bahasa Indonesia. Hal ini menunjukkan bahwa belum ada artikel yang dimuat di JKIP yang menggunakan bahasa asing, terutama Bahasa Inggris.

\section{4) Jumlah Penulis}

Jumlah penulis yang telah berkontribusi pada penulisan 76 artikel yang dimuat di JKIP adalah sebanyak 89 orang yang berasal dari berbagai instansi dan profesi. Dari total 89 penulis, dapat diketahui bahwa penulis yang berjenis kelamin laki-laki sebanyak 34 orang $(38,2 \%)$ dan penulis berjenis kelamin perempuan sebanyak 55 orang $(69,8 \%)$. Hal ini menunjukkan bahwa penulis yang ada di JKIP didominasi oleh perempuan.

\section{5) Tingkat Kolaborasi Penulis}

Kemudian mengenai tingkat kolaborasi penulis dalam suatu artikel yang dipublikasikan oleh JKIP selama periode 2014 sampai 2018 menunjukkan bahwa dari total keseluruhan artikel yakni sebanyak 76 buah, terungkap bahwa jumlah artikel terbanyak ditulis oleh 3 orang pengarang yaitu sebanyak 45 judul artikel $(59,21 \%)$, artikel yang ditulis oleh 1 orang penulis sebanyak 17 artikel (22,37\%), artikel yang ditulis oleh 2 orang sebanyak 11 artikel, serta jumlah artikel paling sedikit yaitu sebanyak 3 artikel ditulis oleh 4 penulis (3,95\%). Apabila memperhatikan secara keseluruhan artikel yang dimuat pada Junral Kajian Informasi Dan Perpustakaaan (JKIP) menunjukkan penulis kolaborasi lebih mendominasi dibandingkan dengan penulis tunggal.

\section{Tabel 3. Kepengarangan pada JKIP}

\begin{tabular}{|c|c|c|c|c|c|c|c|}
\hline \multirow{2}{*}{$\begin{array}{c}\text { Jumlah } \\
\text { Pengarang }\end{array}$} & \multicolumn{5}{|c|}{ JumlahArtikel } & \multirow{2}{*}{ Jumlah } & \multirow{2}{*}{$\%$} \\
\hline & 2014 & 2015 & 2016 & 2017 & 2018 & & \\
\hline 1 & 0 & 9 & 2 & 1 & 5 & 17 & $22,37 \%$ \\
\hline 2 & 0 & 4 & 2 & 4 & 1 & 11 & $14,47 \%$ \\
\hline
\end{tabular}




\begin{tabular}{|c|c|c|c|c|c|c|c|}
\hline \multirow{2}{*}{$\begin{array}{c}\text { Jumlah } \\
\text { Pengarang }\end{array}$} & \multicolumn{5}{|c|}{ JumlahArtikel } & \multirow{2}{*}{ Jumlah } & \multirow{2}{*}{$\%$} \\
\hline & 2014 & 2015 & 2016 & 2017 & 2018 & & \\
\hline 3 & 14 & 7 & 14 & 9 & 1 & 45 & $59,21 \%$ \\
\hline 4 & 0 & 2 & 1 & 0 & 0 & 3 & $3,95 \%$ \\
\hline Total & 14 & 22 & 19 & 14 & 7 & 76 & $100 \%$ \\
\hline
\end{tabular}

Sumber : Data Penelitian

Masih tentang penuilis kolaborasi dan penulis perorangan pasda artikel-artikel yang dimuat pada Junral Kajian Informasi dan Perpustakaaan (JKIP) selama rentang tahun 2014-2018 penulis gabungan atau kolaborasi lebih mendominasi yakni sebanyak 59 artikel (77,63\%). Sedangkan artikel yang ditulis oleh penulis tunggal hanyasebanyak 17 artikel (22,37\%). Untuk lebih jelasnya mengenai penulis kolaborasi dan penulis tunggal ini dapat dilihat pada table di bawah ini:

Tabel 4. Kepengarangan Perorangan dan Kolaborasi

\begin{tabular}{ccccccccc}
\hline \multirow{2}{*}{ Jumlah Pengarang Jumlah Artikel } & \multirow{2}{*}{ Jumlah } & \multirow{2}{*}{$\%$} \\
\cline { 2 - 7 } & 2014 & 2015 & 2016 & 2017 & 2018 & & \\
\hline Perorang & 0 & 9 & 2 & 1 & 5 & 17 & $22,37 \%$ \\
\hline Kolaborasi & 14 & 13 & 17 & 13 & 2 & 59 & $77,63 \%$ \\
\hline Total & 14 & 22 & 19 & 14 & 7 & 76 & $100 \%$ \\
\hline
\end{tabular}

Sumber : Data penelitian

Dalam menentukan derajat kolaborasi pada Jurnal kajian Informasi dan Perpustakaan (JKIP) UNPAD yang terbit pada rentang tahun 2014-2018, digunakan rumus Subramanyam (1983), yaitu :

$$
\mathrm{C}=\frac{N_{m}}{N_{m+N_{s}}}
$$

Berdasarkan kajian, dapat diketahui bahwa total artikel yang ditulis oleh penulis kolaborasi adalah $59\left(\mathrm{~N}_{\mathrm{m}}=59\right)$ dan total artikel yang ditulis oleh penulis tunggal adalah $17\left(\mathrm{~N}_{\mathrm{s}}=17\right)$, maka derajat kolaborasi $(\mathrm{C})$ yang 
ada pada JKIP periode 2014-2018 adalah :

$$
\mathrm{C}=\frac{59}{59+17}=0,78
$$

Berdasarkan perhitungan menggunakan rumus Subramanyam tersebut, diketahui bahwa derajat kolaborasi $(\mathrm{C})$ yang diperoleh adalah 0,78 . Hal ini menunjukkan bahwa nilai $\mathrm{C}$ lebih besar dari 0,5 dan kurang dari $1(0,5<\mathrm{C}$ $<1)$. Berdasarkan hal tersebut, maka dapat disimpulkan bahwa artikel yang ditulis secara berkolaborasi lebih banyak daripada secara perorangan/individu.

\section{6) Produktivitas Penulis}

Tabel 5 menunjukkan distribusi pengarang dan artikel pada JKIP periode 2014-2018. Pada tabel tersebut dapat dilihat bahwa jumlah pengarang terbanyak ada pada tahun 2016 yaitu sebanyak 39 orang penulis yang menghasilkan 19 artikel, sedangkan jumlah penulis paling sedikit ada pada tahun 2018 yaitu sebanyak 10 orang penulis yang menghasilkan 7 artikel. Pada tahun 2014 terdapat 31 penulis dan menghasilkan 14 artikel, pada tahun 2015 terdapat 32 penulis yang menghasilkan 22 artikel, dan pada tahun 2017 terdapat 28 penulis yang berkontribusi dalam penulisan 14 artikel. Adanya jarak antara jumlah penulis pada tahun 2014-2017 dan 2018 ini dikarenakan hanya ada 1 nomor jurnal yang terbit pada tahun 2018, sedangkan pada tahun 2014 hingga 2017 JKIP mengeluarkan 2 nomor pada setiap tahunnya.

\section{Tabel 5. Distribusi Pengarang dan Artikel}

\begin{tabular}{ccccc}
\hline $\begin{array}{c}\text { Tahun } \\
\text { Terbit }\end{array}$ & $\begin{array}{c}\text { Jumlah } \\
\text { Pengarang }\end{array}$ & $\begin{array}{c}\text { Jumlah } \\
\text { Artikel }\end{array}$ & $\begin{array}{c}\text { Persentase } \\
\text { Pengarang }\end{array}$ & $\begin{array}{c}\text { Persentase } \\
\text { Artikel }\end{array}$ \\
\hline 2014 & 31 & 14 & $22,14 \%$ & $18,42 \%$ \\
\hline 2015 & 32 & 22 & $22,86 \%$ & $28,95 \%$ \\
\hline 2016 & 39 & 19 & $27,86 \%$ & $25 \%$ \\
\hline 2017 & 28 & 14 & $20 \%$ & $18,42 \%$ \\
\hline 2018 & 10 & 7 & $7,14 \%$ & $9,21 \%$ \\
\hline Total & 140 & 76 & $100 \%$ & $100 \%$ \\
\hline
\end{tabular}

Sumber : Data penelitian 
Tabel 6 menunjukkan produktivitas penulis beserta daftar peringkat produktivitas penulis 1-9 dari 89 penulis yang paling produktif dalam penulisan karya ilmiah pada JKIP tahun 2014-2018. Berdasarkan tabel tersebut, dapat dilihat bahwa penulis yang menduduki peringkat pertama sebagai penulis paling produktif adalah Pawit M. Yusup yang telah menulis artikel sebanyak 12 buah, baik secara individu maupun secara kolaborasi. Peringkat kedua diduduki oleh Encang Saepudin dan Rully Khairul Anwar yang menghasilkan 9 artikel. Nuning Kurniasih menduduki peringkat ketiga dengan 8 artikel, selanjutnya ada Ninis Agustini Damayani, Agus Rusmana, Saleha Rodiah, Sukaesih, Tine Silvana Rachmawati dan Yunus Winoto sebagai peringkat keempat yang telah menulis masing-masing sebanyak 6 artikel. Sebanyak 66 penulis menduduki peringkat produktivitas terendah, yaitu peringkat 9, karena hanya menghasilkan 1 judul artikel. Untuk lebih rinci lagi, dapat dilihat pada Tabel 6.

Tabel 6. Penulis JKIP Yang Paling Produktif Selama Periode 2014-2018

\begin{tabular}{lcc}
\multicolumn{1}{c}{ Nama Penulis } & Jumlah Artikel & Peringkat Produktivitas \\
\hline Pawit M Yusup & 12 & 1 \\
\hline EncangSaepudin & 9 & 2 \\
\hline RullyKhaerul Anwar & 9 & 2 \\
\hline NuningKurniasih & 8 & 3 \\
\hline NinisAgusiniDamayani & 6 & 4 \\
\hline AgusRusmana & 6 & 4 \\
\hline SalehaRodiah & 6 & 4 \\
\hline Sukaesih & 6 & 4 \\
\hline Tine SilvanaRachmawati & 6 & 4 \\
\hline YunusWinoto & 6 & 4 \\
\hline 3 PenulisLainnya & 5 & 5 \\
\hline 4 penulislainnya & 4 & 6 \\
\hline 2 penulislainnya & 3 & 7 \\
\hline 4 penulislainnya & 2 & 8 \\
\hline 66 penulislainnya & 1 & 9 \\
\hline
\end{tabular}

Sumber : data penelitian 


\section{7) Sebaran Instansi dan Profesi Penulis}

Tabel 7 menunjukkan bahwa dari total 42 instansi yang berpartisipasi dalam penulisan artikel pada JKIP 2014-2018, Prodi Ilmu Perpustakaan Universitas Padjadjaran menduduki tingkat partisipasi tertinggi yaitu sebanyak 139 kali (76,36\%), kemudian diikuti oleh Pordi Ilmu Perpustakaan di luar Universitas Padjadjaran sebanyak 9 kali (4,95\%), berbagai jurusan dari berbagai perguruan tinggi sebanyak 6 kali (3,30\%), perpustakaan perguruan tinggi sebanyak 4 kali (2,20\%), dan instansi lainnya sebanyak 24 (13,19\%).

\section{Tabel 7. Sebaran Instansi}

\begin{tabular}{lcc}
\hline \multicolumn{1}{c}{ Jenis Instansi } & Frekuensi & Persentase \\
\hline $\begin{array}{l}\text { Program Studi Ilmu Perpustakaan Universitas } \\
\text { Padjadjaran }\end{array}$ & 139 & $76,36 \%$ \\
\hline Program Studi Ilmu Perpustakaan di luar UNPAD & 9 & $4,95 \%$ \\
\hline Berbagai Jurusan dari berbagai Perguruan Tinggi & 6 & $3,30 \%$ \\
\hline Perpustakaan Perguruan Tinggi & 4 & $2,20 \%$ \\
\hline Instansi Lainnya $\quad$ Total & 24 & $13,19 \%$ \\
\hline
\end{tabular}

Sumber : Data penelitian

Selanjutnya pada tabel 8 menggambarkan bahwa profesi penulis yang paling banyak berpartisipasi dalam penulisan artikel adalah dosen yaitu sebanyak 119 kali (65,38\%), pustakawan dan pegawai sebanyak 6 kali (3,30\%), kepala perpustakaan sebanyak 2 kali $(1,10 \%)$, guru dan mahasiswa S2 sebanyak 1 kali $(0,55 \%)$, dan penulis yang profesinya tidak dicantumkan sebanyak 47 kali $(25,82 \%)$. 
Tabel 8. Profesi Penulis

\begin{tabular}{lcc}
\hline \multicolumn{1}{c}{ Profesi } & Frekuensi & Persentase \\
\hline Dosen & 119 & $65,38 \%$ \\
\hline Pustakawan & 6 & $3,30 \%$ \\
\hline Pegawai & 6 & $3,30 \%$ \\
\hline KepalaPerpustakaan & 2 & $1,10 \%$ \\
\hline Guru & 1 & $0,55 \%$ \\
\hline Mahasiswa S-2 & 1 & $0,55 \%$ \\
\hline TidakJelas & 47 & $25,82 \%$ \\
\hline \multicolumn{1}{c}{ Total } & 182 & $100 \%$ \\
\hline
\end{tabular}

Sumber : Data penelitian

\section{Simpulan}

Berdasarkan hasil penelitian mengenai analisis bibliometrika ini dapat diketahui bahwa dalam rentang tahun 2014-2018 Jurnal Kajian Informasi dan Perpustakaan (JKIP) periode 2014 s.d 2018 telah menerbitkan sebanyak 9 terbitan jurnal dengan rata-rata setiap volume menerbitkan dua nomor kecuali pada tahun 2018 hanya menerbitkan satu nomor. Adapun jumal artikel yang diterbitkan sekitar 76 artikel dengan rata-rata artikel untuk setiap terbitan sebanyak 7 artikel. Berdasarkan referensi yang digunakan, dari 76 artikel tersebut menggunakan referensi sitiran sebanyak 1.031 judul referensi dengan Bahasa yang paling banyak dipakai menggunakan Bahasa Indonesia. Jumlah penulis yang berkontribusi sebanyak 89 penulis yang sebagian merupakan penulis kolaborasi dari 3 orang pengarang. Sedangkan dilihat dari Instansi penulis diketahui bahwa produktivitas penulis yang paling tinggi berasal dari kalangan dosen dari instansi Program Studi Ilmu Perpustakaan Universitas Padjadjaran. 


\section{Daftar Pustaka}

Andreas, Ana. Measuring Academic Research: How to undertake a bibliometric study. Chandos Publishing, 2009.

Adnan, Zifirdaus, dan I Zifirdaus. Merebut Hati Audiens Internasional: Strategi Ampuh Meraih Publikasi di Jurnal Ilmiah. Jakarta: Gramedia, 2005.

Jurnal Kajian Informasi \& Perpustakaan Website. Jurnal Kajian Informasi \& Perpustakaan Website. 2018. http://jurnal.unpad.ac.id/jkip/index (diakses 2018).

Rahayu, Sri, and Abdul Rahman Saleh. 2017. "Studi Bibliometrik dan Sebaran Topik Penelitian pada Jurnal Hayati Terbitan 2012-2016.” Pustakaloka 201218.

Suryoputro, Gunawan, Sugeng Riadi, dan Ali Sya'ban. Menulis Artikel Untuk Jurnal Ilmiah. Jakarta: Uhamka Press, 2012.

Wahyudi, Agus. "ANALISIS POLA PRODUKTIVITAS PENULIS ARTIKEL BIDANG PERPUSTAKAAN DAN INFORMASI DI INDONESIA : SUATU KAJIAN BIBLIOMETRIKA.” Jurnal Pustakawan Indonesia 14.

Widuri, Noorika Retno. “Tingkat Kolaborasi, Produktivitas penulis dan artikel metrik pada jurnal ." Jurnal Berkala Ilmu Perpustakaan dan Informasi, 2018. 